\title{
Evaluation of Aframomum melegueta aqueous seed extract on food and water consumption in albino rats
}

\author{
Nosiri $\mathrm{C}^{1 *}$, Anyanwu $\mathrm{C}^{2}$, Agim $\mathrm{C}^{1}$ and Nwaogwugwu $\mathrm{C}^{1}$ \\ ${ }^{1}$ Department of Biochemistry, Faculty of Biological and Physical SciencesAbia State University, Uturu, Nigeria \\ ${ }^{2}$ Bizmart Pharmaceuticals, Houston, TX
}

\begin{abstract}
This experiment was carried out to evaluate the effect of seed extract of Aframomum melegueta on water and feed intake in albino rats. The aqueous seed extract of Aframomum melegueta was administered (p.o) to the animals for 28 days and water and food given $7 \mathrm{hrs}$ daily. The animals were divided into four groups of six rats both of the males and females comprising of control groups, 200, 400 and $600 \mathrm{mg} / \mathrm{kg}$ extract. There was a gradual increase in food intake which affected their body weights dose dependently. Water consumption by all the treated groups from both male and female increased significantly $(\mathrm{P} \leq 0.05)$ when compared with the control groups. The reason could be that there was alteration in the hypothalamus which is a centre that controls appetite and thirst. Conclusively, it induced Polydypsia which represents a compensatory mechanism that maintains total body fluids within normal limits and therefore could be used safely for the management of diseases.
\end{abstract}

Keywords: Aframomum melegueta, feed, Hypothalamus, Water

\section{INTRODUCTION}

Herbs play important role in medicine. The pharmacological treatment of disease began long ago with the use of herbs[1]. Methods of folk healing throughout the world commonly used herbs as part of their tradition. Medicinal plants are the "backbone" of traditional medicine, and it has been reported that 3.3 billion people in the less developed countries utilize medicinal plants on a regular basis[2].Hunger and thirst are associated with the Hypothalamus. Hypothalamus participates in the control of appetite with the lateral nuclei serving as the feeding centre. When this feeding centre is stimulated hyperphagia occurs and when destroyed causes lack of appetite and progressive inanition, a condition characterized by loss of weight, decreased metabolism and muscle weakness [3]. On the other hand, Polydypsia represents a compensatory mechanism in order to maintain total body fluids within normal limits [4]. Most disorders of water balance are due to the inability of the kidney to conserve water because of the anti-diuretic hormone, Arginine Vasopressin ( AVP) deficiency or renal insensitivity to AVP [3].Aframomum melegueta (alligator pepper) (Zingiberaceae) is a plant that possesses both medicinal and nutritive properties. The traditional names of the seed popularly known as alligator pepper in Nigeria are Ose-oji (Igbo), Atare (Yoruba), and Citta (Hausa). It is popularly used in herbal medicine against a wide range of ailments by many cultures in Africa especially in Nigeria. Aframomum melegueta is widely used as a spice in food, served and eaten during entertainment with kola nuts to visitors. The ethanolic seed extract possesses hypoglycemic and tissue protective properties [5]. Its aqueous extract has been shown pharmacologically to reduce gestational weight in pregnant rats [6]. The spice is used in West Africa for the purposes of alleviating stomach ache and diarrhoea, cardiovascular diseases, diabetes and inflammation [7], as an aphrodisiac [8] and a remedy for snakebites and scorpion stings [9]. The qualitative phytochemical screening has shown the presence of alkaloids, saponins, tannins, flavonoids, and cardiac glycosides [10].The rate of consumption of the seed of this plant and its use in the treatment of various diseases necesitated the evaluation of its effect on hunger and thirst.

\section{MATERIALS AND METHODS}

2.1 Plant material

The seeds of Aframomum melegueta used in this present study was purchased at Eke Okigwe, Imo State, Nigeria in January, 2016. This plant material was brought to the Department of Biochemistry, Abia State University Uturu in an airtight polyethylene container where the analysis was carried out and was authenticated by Dr. Bob Ezuma of Plant Science and Biotechnology of the University. The seeds were sun dried for 7 days. The dried seeds were milled into fine powder and then macerated in sterile distilled water $(100 \mathrm{~g}$ in $500 \mathrm{~mL})$ for $24 \mathrm{~h}$. The extract was decanted and filtered through a membrane filter using membrane filtration technique with 
suction pressure, and the filtrate was evaporated using rotary evaporator in other to concentrate the extract. The concentrate was dispensed into airtight sterile container and stored at $4{ }^{\circ} \mathrm{C}$ in the refrigerator until usage.2.2 Experimental ModelA total of 48 rats ( 24 males) and ( 24 females) aged about seven weeks were purchased from the animal house of the Department of Veterinary Medicine, University of Nigeria, Nsukka and used for this study. The animals were allowed to acclimatize for two weeks in the animal house of Biochemistry Department, Faculty of Biological and Physical Sciences, Abia State University with access to food and water ad libitum before the commencement of the study. The wistar rats were randomly divided into four groups of six animals (6/sex/group) for the males and for the females (Group I-IV males and Group I-IV females). Group I received $2 \mathrm{ml}$ of $0.9 \%$ normal saline in both male and female groups. Group II received $(200 \mathrm{mg} / \mathrm{kg})$ body weight of the aqueous extract. Group III received $(400 \mathrm{mg} / \mathrm{kg})$ of the extract. Group IV rats received $(600 \mathrm{mg} / \mathrm{kg})$ body weight of the aqueous extract for the males and for the females. The extract was administered to the rats by oral gavage daily for 28 days and water and feed were given to them $7 \mathrm{hrs}$ daily. The statistical analysis of result was done using students package for social sciences (SPSS) version 20 computer software and were expressed as mean \pm SD [standard deviation]. Statistical analysis was performed by one way analysis of variance (ANOVA). And values of $\mathrm{p} \leq 0.05$ at $95 \%$ level of significance was used to assess significant difference between control and treated groups.

\section{RESULTS}

Table I: Effect of aqueous seeds extract of Aframomum melegueta on food consumption (g) of male and female wistar rats

\begin{tabular}{|l|l|l|l|l|l|}
\hline Weeks & Sex & $\begin{array}{l}\text { Group 1 } \\
\text { Control }\end{array}$ & $\begin{array}{l}\text { Group 2 } \\
(200 \mathrm{mg} / \mathrm{kg})\end{array}$ & $\begin{array}{l}\text { Group 3 } \\
(400 \mathrm{mg} / \mathrm{kg})\end{array}$ & $\begin{array}{l}\text { Group 4 } \\
(600 \mathrm{mg} / \mathrm{kg})\end{array}$ \\
\hline \multirow{2}{*}{ Week 1 } & Male & $89.29 \pm 4.49^{\mathrm{a}}$ & $90.89 \pm 4.59^{\mathrm{a}}$ & $90.26 \pm 3.67^{\mathrm{a}}$ & $88.24 \pm 2.76^{\mathrm{a}}$ \\
\cline { 2 - 6 } & Female & $84.86 \pm 3.56^{\mathrm{a}}$ & $89.71 \pm 4.03^{\mathrm{a}}$ & $107.33 \pm 1.25^{\mathrm{b}}$ & $89.61 \pm 2.76^{\mathrm{a}}$ \\
\hline \multirow{2}{*}{ Week 2 } & Male & $105.53 \pm 1.83^{\mathrm{a}}$ & $103.97 \pm 2.37^{\mathrm{a}}$ & $103.97 \pm 2.37^{\mathrm{a}}$ & $106.13 \pm 3.84^{\mathrm{a}}$ \\
\cline { 2 - 6 } & Female & $102.19 \pm 3.21^{\mathrm{a}}$ & $101.93 \pm 2.07^{\mathrm{a}}$ & $106.90 \pm 0.75^{\mathrm{a}}$ & $102.93 \pm 1.29^{\mathrm{a}}$ \\
\hline \multirow{2}{*}{ Week 3 } & Male & $108.90 \pm 0.81^{\mathrm{ab}}$ & $109.70 \pm 0.62^{\mathrm{b}}$ & $107.39 \pm 1.08^{\mathrm{ab}}$ & $106.31 \pm 0.96^{\mathrm{a}}$ \\
\cline { 2 - 6 } & Female & $106.03 \pm 1.12^{\mathrm{a}}$ & $106.46 \pm 0.94^{\mathrm{a}}$ & $104.41 \pm 1.11^{\mathrm{a}}$ & $106.44 \pm 1.08^{\mathrm{a}}$ \\
\hline \multirow{2}{*}{ Week 4 } & Male & $105.94 \pm 1.02^{\mathrm{a}}$ & $109.31 \pm 0.68^{\mathrm{b}}$ & $107.90 \pm 0.87^{\mathrm{ab}}$ & $106.99 \pm 0.78^{\mathrm{ab}}$ \\
\cline { 2 - 7 } & Female & $106.61 \pm 0.87^{\mathrm{a}}$ & $104.91 \pm 1.24^{\mathrm{a}}$ & $104.21 \pm 1.23^{\mathrm{a}}$ & $105.01 \pm 0.86^{\mathrm{a}}$ \\
\hline
\end{tabular}

Values represent the mean \pm SD for $\mathrm{N}=6$. Values in the same row bearing the same alphabets are not significantly different from each other at $\mathrm{P} \leq 0.05$

Table II: Effects of aqueous extract of $A$. Melegueta on the body weight of male and female wistar rats.

\begin{tabular}{|l|l|l|l|l|l|}
\hline Weeks & Sex & $\begin{array}{l}\text { Group 1 } \\
\text { Control }\end{array}$ & $\begin{array}{l}\text { Group 2 } \\
(200 \mathrm{mg} / \mathrm{kg})\end{array}$ & $\begin{array}{l}\text { Group 3 } \\
(400 \mathrm{mg} / \mathrm{kg})\end{array}$ & $\begin{array}{l}\text { Group 4 } \\
(600 \mathrm{mg} / \mathrm{kg})\end{array}$ \\
\hline \multirow{2}{*}{ Week 1 } & Male & $119.00 \pm 2.71^{\mathrm{a}}$ & $135.57 \pm 1.91^{\mathrm{b}}$ & $139.19 \pm 1.19^{\mathrm{b}}$ & $153.29 \pm 1.69^{\mathrm{c}}$ \\
\cline { 2 - 6 } & Female & $109.86 \pm 1.55^{\mathrm{a}}$ & $135.29 \pm 1.38^{\mathrm{b}}$ & $138.86 \pm 1.57^{\mathrm{bc}}$ & $143.57 \pm 2.63^{\mathrm{c}}$ \\
\hline \multirow{2}{*}{ Week 2 } & Male & $129.72 \pm 3.09^{\mathrm{a}}$ & $138.57 \pm 0.53^{\mathrm{b}}$ & $140.57 \pm 0.10^{\mathrm{b}}$ & $148.29 \pm 1.60^{\mathrm{c}}$ \\
\cline { 2 - 6 } & Female & $106.00 \pm 1.87^{\mathrm{a}}$ & $135.43 \pm 1.53^{\mathrm{b}}$ & $145.00 \pm 1.16^{\mathrm{c}}$ & $140.71 \pm 2.25^{\mathrm{c}}$ \\
\hline \multirow{2}{*}{ Week 3 } & Male & $118.57 \pm 3.96^{\mathrm{a}}$ & $139.00 \pm 0.49^{\mathrm{b}}$ & $138.00 \pm 0.54^{\mathrm{b}}$ & $149.43 \pm 1.04^{\mathrm{c}}$ \\
\cline { 2 - 6 } & Female & $108.57 \pm 1.45^{\mathrm{a}}$ & $138.43 \pm 1.15^{\mathrm{b}}$ & $146.71 \pm 1.34^{\mathrm{c}}$ & $144.29 \pm 1.69^{\mathrm{c}}$ \\
\hline \multirow{2}{*}{ Week 4 } & Male & $122.43 \pm 1.80^{\mathrm{a}}$ & $140.57 \pm 0.43^{\mathrm{b}}$ & $139.71 \pm 0.61^{\mathrm{b}}$ & $148.86 \pm 3.02^{\mathrm{c}}$ \\
\cline { 2 - 6 } & Female & $108.57 \pm 0.90^{\mathrm{a}}$ & $139.14 \pm 0.74^{\mathrm{b}}$ & $141.00 \pm 1.70^{\mathrm{b}}$ & $145.14 \pm 1.06^{\mathrm{c}}$ \\
\hline
\end{tabular}

Values represent the mean \pm SD for $N=6$. Values in the same row bearing the same alphabets are not significantly different from each other at $\mathrm{P} \leq 0.05$

Table III: Effect of aqueous seeds extract of Aframomum melegueta on water intake (ml) of male and female wistar rats 


\section{DISCUSSION}

\begin{tabular}{|l|l|l|l|l|l|}
\hline Days & Sex & $\begin{array}{l}\text { Group 1 } \\
\text { Control }\end{array}$ & $\begin{array}{l}\text { Group 2 } \\
(200 \mathrm{mg} / \mathrm{kg})\end{array}$ & $\begin{array}{l}\text { Group 3 } \\
(400 \mathrm{mg} / \mathrm{kg})\end{array}$ & $\begin{array}{l}\text { Group 4 } \\
(600 \mathrm{mg} / \mathrm{kg})\end{array}$ \\
\hline \multirow{2}{*}{ Day1 } & Male & $122.75 \pm 14.56$ & $124.87 \pm 12.26$ & $131.85 \pm 28.21$ & $128.17 \pm 29.69$ \\
\cline { 2 - 6 } & Female & $120.82 \pm 13.59$ & $118.00 \pm 23.27$ & $124.55 \pm 11.57$ & $116.90 \pm 16.49$ \\
\hline \multirow{2}{*}{ Day 28 } & Male & $143.23 \pm 19.75$ & $150.83 \pm 15.56$ & $164.95 \pm 31.82$ & $149.95 \pm 27.00$ \\
\cline { 2 - 6 } & Female & $139.43 \pm 10.76$ & $141.10 \pm 21.84$ & $149.68 \pm 11.38$ & $142.13 \pm 18.47$ \\
\hline \multirow{2}{*}{ Weight gain } & Male & 20.48 & 25.96 & 33.10 & 21.78 \\
\cline { 2 - 6 } & Female & 18.61 & 23.10 & 25.13 & 25.23 \\
\hline \multirow{2}{*}{$\%$ weight gain } & Male & 14.30 & 17.21 & 16.07 & 14.52 \\
\cline { 2 - 6 } & Female & 13.35 & 16.37 & & 17.75 \\
\hline
\end{tabular}

Values represent the mean \pm SD for $\mathrm{N}=6$. Values in the same row bearing the same alphabets are not significantly different from each other at $\mathrm{P} \leq 0.05$

The effect of different doses of aqueous seed extract of Aframomum melegueta on food consumption by the wistar rats showed a slight increase in the amount of food taken throughout the period of the study when compared with both the male and female control groups. This showed that apetite was stimulated. Hypothalamus participates in the control of appetite as the lateral nuclei serve as the feeding centre which when stimulated causes hyperphagia [3]. This slight increase in feed intake affected their body weights for there was improvement in the percentage body weight of all the treated animals. It has been reported that weight gain is due to an imbalance between dietary intake and energy expenditure [11].The result of the effect of aqueous seed extract of Aframomum melegueta on water intake in the male group showed an increase in water consumption all through the four week of examination. There was no significant difference ( $P>0.05)$ between group II ( 200 $\mathrm{mg} / \mathrm{kg}$ ) and group III (400 mg/kg), but there was in group IV when compared to control. For the female groups, there was also significant increase in water consumption in the tested groups when compared with the control group. This could be as a result of alteration on the hypothalamus. The hypothalamus controls water consumption and any alteration signifies that the hypothalamus has been affected [12]. If the hypothalamus is altered there is a tendency of increased water intake (diabetes insipidus) which occurs when there is lack of secretion of Antidiuretic hormone (ADH) centrally or even when released could be nephrogenic [13]. The balance between water loss and water intake results from interactions between the hypothalamus, the pituitary gland and the kidney, and is maintained by thirst and renal excretion of water and salt [4]. The extract may have induced polydypsia through central or nephrogenic mechanisms by stimulating the paraventricular nucleus in the hypothalamus to release Arginine vasopressin (AVP)[14]

\section{CONCLUSION}

The seed extract showed a stimulant effect on the hypothalamus by inducing polydipsia and hyperphargia thereby maintaining food and especially water balance within normal limits hence no mortality was recorded throughout the period of study. It may be concluded that the plant is safe for use even in the management of diseases

\section{REFERENCES}

[1] Schulz, V., Hänsel, R. \& Tyler, V.E. Rational Phytotherapy. A Physician's Guide to Herbal Medicine, 4th Ed., Berlin, Springer-Verlag (2001)

[2] Davidson-Hunt I. Ecological ethnobotany: stumbling toward new practices and paradigms. MASA J. 2000;16:1-13.

[3] Guyton C and Hall E. Contribution of the Cerebellum and Basal Ganglia to overall MotorControl. In: John E. H. ed. Medical Physiology. (Elsevier Inc., Philadelphia, Pensylvania, $\quad 2006$ ) 710-711.

[4] Johan PS. Approach to Polyuria and Polydipsia in the Dog Department of Companion Animal Clinical Studies, Faculty of Veterinary Science, University of PretoriaOnderstepoort, South Africa. 2008.

[5] Chidi Nosiri, Stanley Okereke, Chukwuma Anyanwu, Chieme Chukwuduruo and Chijindu Nwankwo. Responses of Liver and Pancreatic Cells to Ethanolic Seed Extract of Aframomum Melegueta in Alloxan-Induced Diabetic Rats . Journal of Medicinal Plant Studies. 4(5): 2016, 112-116

[6] Inegbenebor U, Ebomoyi MI , Onyia KA, Amadi K, Aigbiremolen AE Nigerian Journal of Physiological Sciences 24 (2): 2009, $165-169,20$

[7] Ilic N, Schmidt BM, Poulev A, Raskin I. Toxicological evaluation of grains of paradise (Aframomum melegueta) (Roscoe) K. Schum. J Ethnopharmacology 127(2): 2010, $352-\quad 6$ 
[8] Kamtchouing P, Mbongue GY, Dimo T, Watcho P, Jatsa HB, Sokeng SD. Effects of Aframomum melegueta and Piper guineense on sexual behaviour of male rats . Behav Pharmacology 13(3): 2002, 243-7

[9] Lans C, Harper T, Georges K, Bridgewater E. Medicinal and ethnoveterinary remedies of hunters in Trinidad . BMC Complementary Alternative Medicine 2001; 1:10.

[10] Agim C and Nosiri C. Evaluation of the Phytochemical and GC-MS analysis of the aqueous seed extract of Aframomum melegueta. Journal of Pharmacognosy and Phytochemistry 6(2): 2017, 101-104

[11] Katherine A. Simpson; Niamh M. Martin; Steve R. Bloom, Hypothalamic Regulation of Appetite Expert Rev Endocrinol Metab. 3(5): 2008, 577-592.

[12] Smith RW and McCann SM. Alteration in food and water intake after hypothalamic lesions in rats. American Journal of Physiology, 1962; 203:366-370

[13] Rang H P, Dale M M, Ritter J M and Moore P K . Pharmacology 5 edn. (Churchill Livingstone UK) 2003

[14] Bisset G W, Barbara J. Clark, and M. L. Errington. Hypothalamic neurosecretory pathways for the release of Vasopressin and Oxytocin in the cat. Journal of Physiology, 217 (1): 1971,111-131. 